Valery GOND ${ }^{1}$

Emilien DuBIEZ

Marine BOULOGNE

Morgan GIGAUD ${ }^{4}$

Adrien PÉROCHES ${ }^{2}$

Alexandre Pennec ${ }^{5}$

Nicolas FAUVET ${ }^{1}$

Régis PeLTie ${ }^{1}$

${ }^{1}$ Cirad

UR BSEF

Campus international

de Baillarguet

34398 Montpellier Cedex 05

France

${ }^{2}$ ONF Cameroun

(Filiale d'ONF International)

BP 35191, Yaoundé

Cameroun

3 Université de Grenoble

UMR 5564 LTHE / UMR 228

Espace Dev

BP 53

38041 Grenoble Cedex 9

France

4 Université d’Orléans

Faculté des Sciences

Dép. de Biologie

Château de la Source

Avenue du Parc Floral

BP 6749

45067 Orléans Cedex 2

France

5 Systèmes d'Information

à Référence Spatiale (SIRS)

Research and Development

Unit

Parc de la Cimaise

Bâtiment I

27 rue du Carrousel

59650 Villeneuve-d'Ascq

France

\section{Dynamic of forest cover and carbon stock change in the Democratic Republic of Congo: Case of wood-fuel supply basin for Kinshasa}

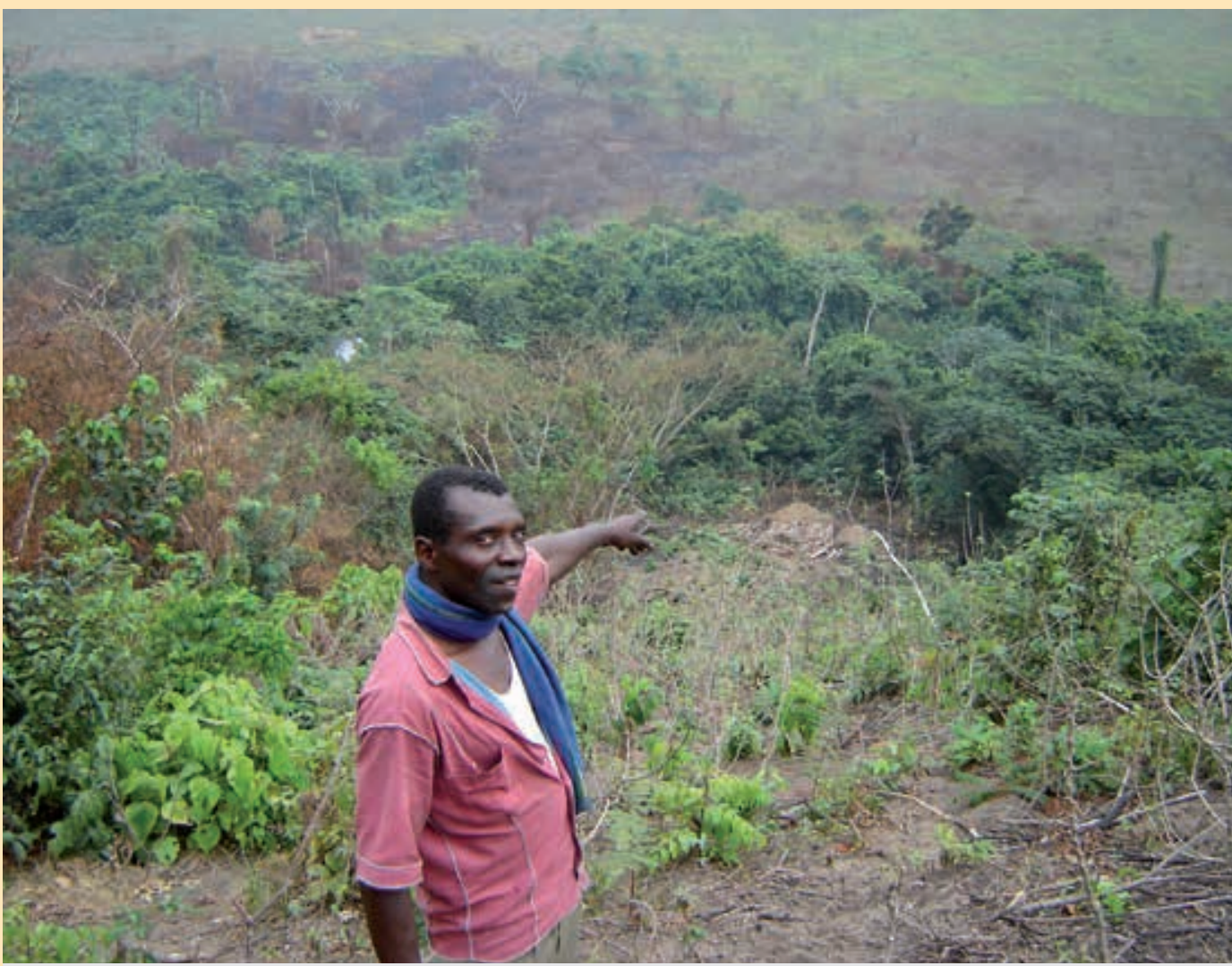

Photo 1.

At the bottom of the Lufimi River valley, on the Bateke plateau, a farmer shows the limits of the field that he created by slashing and burning the gallery forest.

On the other side of the valley, one can see his old fields, where the regular passage of bushfires favors the development of herbaceous savannah to the detriment of forest vegetation.

Photo R. Peltier. 


\section{RÉSUMÉ}

\section{DYNAMIQUES DE CHANGEMENT DE LA COUVERTURE FORESTIÈRE ET DU STOCK DE CARBONE EN RÉPUBLIQUE DÉMOCRATIQUE DU CONGO : LE CAS DE L'APPROVISION- NEMENT EN BOIS-ÉNERGIE DU BASSIN DE KINSHASA}

Afin de contribuer à la mise au point de méthodes de gestion durable des écosystèmes forestiers en Afrique centrale, la question de recherche suivante a été posée : l'analyse de l'évolution de la couverture végétale permet-elle de comprendre et de documenter l'organisation spatiale et les mécanismes de la dégradation des forêts tropicales ? Pour cela, en République démocratique du Congo, le projet Makala a cartographié les arbres et les ressources forestières du bassin d'approvisionnement en bois-énergie de Kinshasa et a essayé de prédire son évolution future. La carte a été réalisée à quatre périodes (1984, 2001, 2006 et 2012) avec une mosaïque de quatre images Landsat. L'estimation de la biomasse aérienne a été faite en 2012, par l'inventaire forestier de 317 parcelles (4 337 arbres de 44 espèces) dans les quatre types de couverture végétale, sur le plateau Batéké. Entre 2000 et 2012, le volume moyen de bois-énergie a chuté de plus de $50 \%$ et les stocks de carbone de $75 \%$ en 28 ans. La réduction drastique du couvert forestier, la baisse significative des périodes de jachère, l'augmentation des surfaces de savane, le déclin des stocks de biomasse et de carbone, constituent des signaux particulièrement forts. Mais ces premières estimations sont dérivées des données d'un petit échantillon, extrapolées au bassin d'approvisionnement. II serait très utile d'augmenter l'échantillonnage, pour approcher des valeurs plus justes et concrètes. L'expérience du projet Makala montre clairement que l'analyse de l'évolution de la couverture végétale permet de comprendre et de documenter l'organisation spatiale et les mécanismes de la dégradation des forêts. Mais seules une politique consciente et une gestion durable des terres des communautés, combinées avec une réintroduction des arbres dans les terres agricoles, peuvent initier un processus de restauration durable.

Mots-clés : bois-énergie, stock de carbone, couvert forestier, dégradation forestière, inventaire forestier, restauration forestière, télédétection, Kinshasa, République démocratique du Congo.

\section{ABSTRACT}

\section{DYNAMICS OF FOREST COVER AND CARBON STOCK CHANGE IN THE DEMOCRATIC REPUBLIC OF CONGO: CASE OF WOOD-FUEL SUPPLY BASIN FOR KINSHASA}

To contribute to the development of methods for the sustainable management of forest ecosystems in Central Africa, the following research question was addressed: can analyses of land cover change help to understand and document the spatial organization and mechanisms of forest degradation? To answer this question in the Democratic Republic of Congo, the Makala project mapped the tree and forest resources of Kinshasa's wood-fuel supply basin and attempted to predict how they would evolve in the future. Maps were made for four periods (1984, 2001, 2006 and 2012) using a mosaic of four LANDSAT images. The above-ground biomass was estimated in 2012 using forest inventories in 317 plots distributed across the four types of plant cover found on the Bateke plateau (4,337 trees and 44 species were recorded). This inventory data combined with the satellite data allowed us to make the first comprehensive assessment of above-ground biomass in the study area. Between 2000 and 2012, the average volume of wood-fuel fell by more than $50 \%$. Over the entire period studied (1984 to 2012), carbon stocks fell by $75 \%$. In the wood-fuel supply area for Kinshasa, the drastic loss of forest cover, shortened fallow periods, savannah encroachment and the decline of biomass and carbon stocks are clear signals of degradation. However, these initial estimations were derived from a small sample that was extrapolated to the entire supply area. It would be very useful to increase sampling in order to obtain more accurate and realistic figures. The experience of the Makala project clearly shows that the analysis of land cover change helps to understand and document the spatial organization and mechanisms of forest degradation. However, only with a sound wood-fuel resource policy and sustainable community land management, combined with very dynamic tree reintroduction on agricultural land, will it be possible to initiate a sustainable process of restoration.

Keywords: wood-fuel, carbon stocks, forest cover, forest degradation, forest inventory, forest restoration, remote sensing, Kinshasa, Democratic Republic of Congo.

\section{RESUMEN}

\section{DINÁMICAS DE CAMBIOS EN LA CUBIERTA FORESTAL Y LAS RESERVAS DE CARBONO EN LA REPÚBLICA DEMOCRÁTICA DEL CONGO: CASO DEL SUMINISTRO DE LEÑA DEL ÁREA DE KINSHASA}

Para contribuir a la puesta a punto de métodos de manejo sostenible de los ecosistemas forestales en África Central, se formuló la siguiente pregunta de investigación: ise pueden comprender y documentar la organización espacial y los mecanismos de degradación de los bosques tropicales analizando la evolución de la cubierta vegetal? Para intentar dar una respuesta, en la República Democrática del Congo el proyecto Makala cartografió árboles y recursos forestales del área de suministro de leña de Kinshasa e intentó predecir su evolución. El mapa se elaboró en cuatro períodos (1984, 2001, 2006 y 2012) a partir de un mosaico de cuatro imágenes Landsat. La biomasa aérea se estimó en 2012 mediante el inventario forestal de 317 parcelas (4 337 árboles de 44 especies) en los cuatro tipos de cobertura vegetal en la meseta Bateké. Entre 2000 y 2012, el volumen promedio de leña cayó más del 50\% y las reservas de carbono disminuyeron un $75 \%$ en 28 años. La drástica reducción de la cubierta forestal, el acortamiento significativo de los períodos de barbecho, el aumento de las áreas de sabana y la disminución de las reservas de biomasa y carbono son indicios muy claros. No obstante, estas primeras estimaciones se obtuvieron de datos de una pequeña muestra que se extrapoló a toda el área de suministro. Sería muy útil aumentar el muestreo para lograr valores más exactos y concretos. La experiencia del proyecto Makala muestra claramente que el análisis de la evolución de la cobertura vegetal permite comprender y documentar la organización espacial y los mecanismos de degradación de los bosques. Sin embargo, sólo se podrá acometer un proceso de restauración duradero combinando voluntad política y manejo sostenible de tierras de las comunidades con la reintroducción de árboles en las tierras agrícolas.

Palabras clave: leña, reserva de carbono, cubierta forestal, degradación forestal, inventario forestal, restauración forestal, teledetección, Kinshasa, República Democrática del Congo. 


\section{Introduction}

Wood-fuel, used in both raw and processed forms (firewood and charcoal), is a major source of energy in Africa, especially for domestic use. Until the 1970s, the abundance of wood resources in Central Africa, their regeneration capacity, and low population densities hid forest degradation and wood-fuel resource depletion. A lack of easily accessible alternative energy, rapid population growth, and the uncontrolled development of large cities over the past few decades have resulted in a growing imbalance between supply and demand that is threatening the sustainability of forest ecosystems. The share of wood-fuel in energy consumption appears to have been widely underestimated because the wood-fuel market is complex and informal, rendering it difficult to quantify and therefore evaluate.

\section{Background and research question}

In Central Africa, human impacts on tropical natural forests are mostly linked to slash-and-burn cultivation (Molinario et al., 2015) and wood-fuel extraction (Megevand, 2014). This is especially true around Kinshasa, the capital of the Democratic Republic of the Congo (DRC). The population of Kinshasa is estimated at 10 million inhabitants, $90 \%$ of whom rely largely on charcoal for cooking. The city's annual needs were assessed at 4.8 million cubic meters of wood equivalent, in the form of firewood or charcoal, with a value of US\$143 (Schure et al., 2011; Schure, 2014). The conglomeration is surrounded by wooded savannah interspersed with gallery forests which are becoming degraded (photo 1). Shifting agriculture, practiced most often in forests, covers most of the demand for food, notably cassava and maize, and charcoal (Peltier et al., 2014a). Pressure on natural forests is increasing and leading to reductions in the length of the fallow periods required to restore soil fertility (Floret and Pontanier 2000; Katembera-Ciza et al., 2015). As a result, the biodiversity and biomass of fallows are steadily diminishing, soils are being leached, and invasive herbaceous plants and shrubs, such as Chromolaena odorata, Pteridium aquilinum and Imperata cylindrica, are beginning to replace forests (Peltier et al., 2014b). Savannah fires penetrate into the most degraded fields bordering the savannah, which may lead to the savannization of the environment and a reduction in the arable land traditionally cultivated by shifting cultivation. Many authors have long considered the impact of small farmers on the degradation of natural formations to be overestimated. In their view, tropical forests are very resilient (Anglo-French Forestry Commission, 1973) and a significant portion of deforestation should be attributed to large agribusiness companies (Fischetti, 2015). However, in the particular case of the gallery forests on the Bateke plateau, small farmers are behind most of the destruction turning the forests into savannahs (Marquant, 2011).

To contribute to the development of methods for the sustainable management of these forest ecosystems, the following research question was posed: "can the analysis of land cover change allow the spatial organization and mechanisms of forest degradation to be understood and documented?"

\section{Lack of information about forest cover and changes in wood-fuel resources}

Existing data on the forest cover, land-use and carbon stock changes in Kinshasa's wood-fuel supply basin are scarce and unreliable. To identify potential options for local decision makers, and the threats and risks posed by the uncontrolled use of wood-fuel resources, a holistic analysis of the entire supply area is required. Such an analysis needs to be based on an understanding of the spatial organization of the landscape to locate and evaluate forest resources.

The objectives of this study were to map the forest stock of the wood-fuel supply basin of the city of Kinshasa to predict its evolution and to propose solutions to end its degradation. The analysis of past and actual land cover used satellite image techniques. The purpose was to understand and document the spatial organization of the study area, mechanisms of forest degradation, and mechanisms for the recovery of forest stands (Gond et al., 2015).

Given the spatial scale and time periods considered, satellite imagery appeared to be a useful tool of analysis (Duveiller et al., 2008). This tool can be used to analyze data sets over several years (Oszwald et al., 2011) and over very large areas (Vancutsem et al., 2009). However, intensive field work must be conducted alongside these satellite measurements to estimate the biomass in space and time.

The study area covered the entire supply basin, an area of $9,000 \mathrm{~km}^{2}$ (figure 1). This area includes part of the Bateke plateau (savannah interspersed with gallery forests) and the Bas-Congo region that originally was densely forested (Boulogne et al., 2013) (photo 2).

\section{Methods}

\section{Satellite imagery processing}

Maps of the land cover of the wood-fuel supply basin were made for four periods (1984, 2001, 2006 and 2012) using a mosaic of four LANDSAT images (figure 1). Two remote sensing sensors were used, Landsat-5 TM for 1984 and Landsat-7 ETM + for 2001, 2006 and 2012. Mid-infrared [1.55-1.75 microns], near infrared [0.78 to 0.9 microns] and red [0.63 to 0.69 microns] spectral bands were used. For each image, radiometric corrections were applied from digital number (DN) to apparent reflectance. At the same time, an atmospheric correction was performed based on standard atmospheric transparency data using the $5 \mathrm{~S}$ model (Kergomard, 2000). A cloud mask was performed for each image in order to avoid disruption of the classification model. We cumulated the footprints of the stripes on the Landsat-7 ETM+ (2006 and 2012) images to obtain a stripe mask. The surfaces from these two masks were subsequently systematically removed from all of the calculations. 


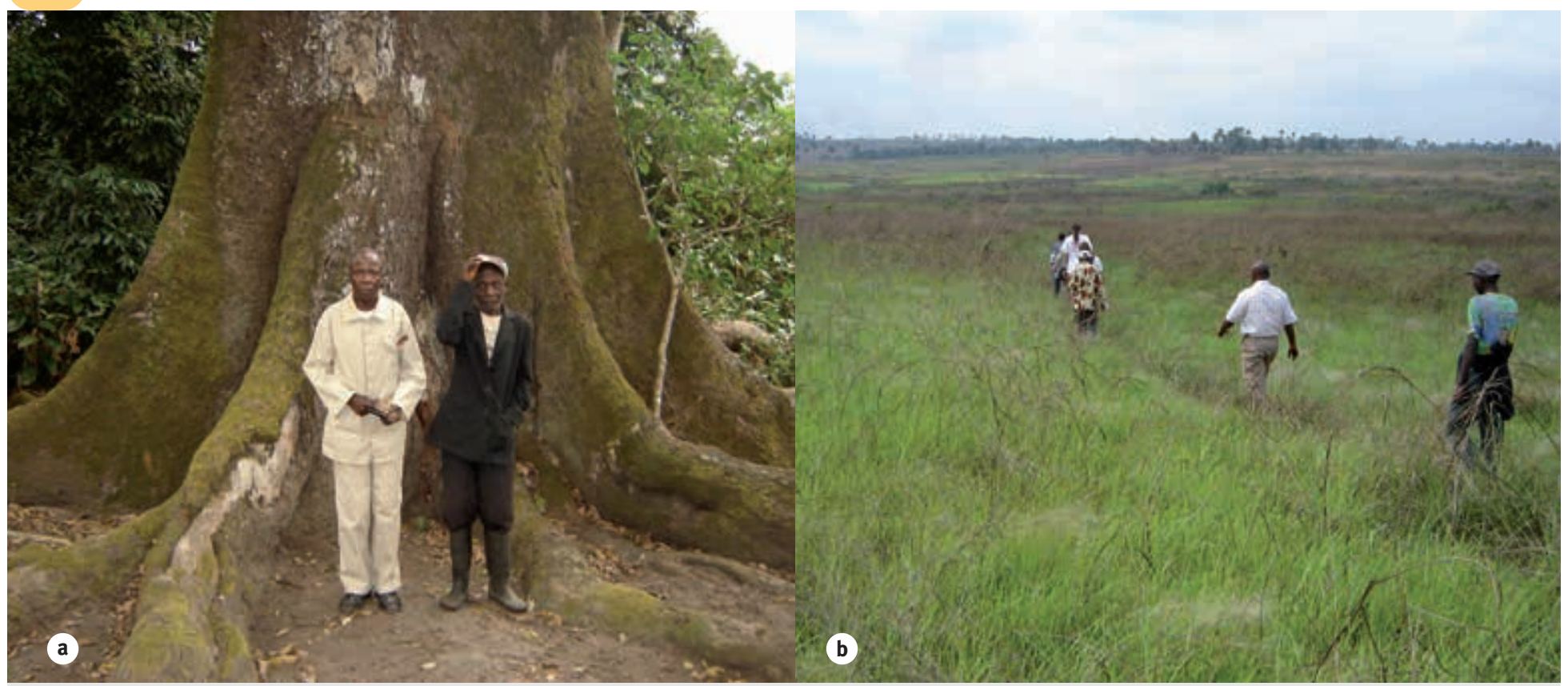

\section{Photo 2.}

The tall trees of the original forest only remain in some sacred forests (a). Elsewhere, particularly in Bas-Congo, savannah, interspersed with fields and punctuated with rare palm trees, have replaced this forest (b).

Photos R. Peltier.

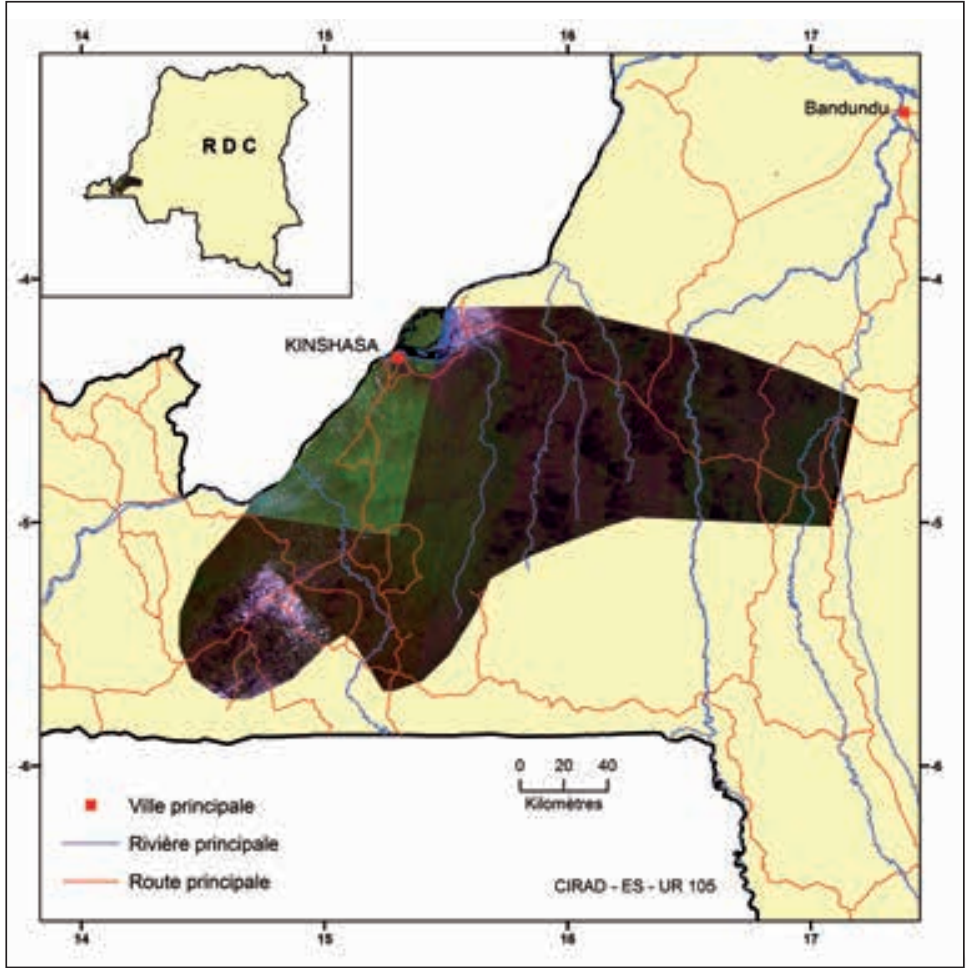

Figure 1.

Location of the wood-fuel supply basin around the city of Kinshasa (DRC).

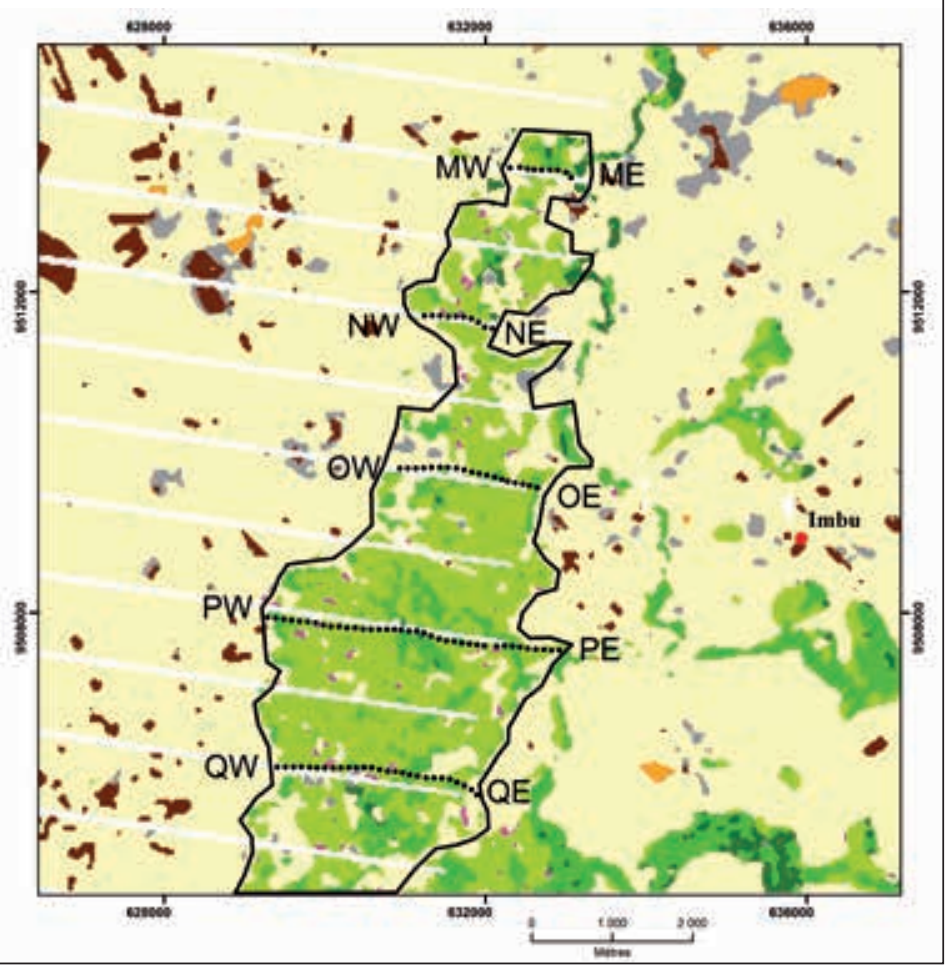

Figure 2.

Location of inventory plots (black spots on the map),

in the four types of vegetation, along five transects of the Lufimi Valley. 


\section{Fields surveys}

Conducted in August 2012, 283 field surveys allowed us to realize a typology of land and build a training zones database (GPS, photo, description of vegetation structure). These training areas were used in the supervised classification model (maximum likelihood algorithm) to map land cover of the 2012 image. A median spatial filter ( $3 \times 3$ pixels) was applied to limit the "salt-and-pepper" effect of the classification. Four vegetation classes were mapped on the 2012 image (savannah, young fallow, old fallow and forest). The statistical validation was determined by the confusion matrix and Kappa index (Oszwald et al., 2011). The classification of the 2012 image had an overall accuracy of $82 \%$ (table I) and a Kappa coefficient of 0.89 , which was quite satisfactory. We then used older satellite data to map the years 2006, 2001 and 1984, using the spectral and visual correspondences of the four vegetation types identified in 2012.

\section{Biomass measurements}

The inventory work was carried out in the Lufimi River Valley on the Bateke plateau (Gigaud, 2012). The height and diameter at breath height (dbh) of a total of 4,337 trees on 317 plots (20 m radius) were measured along transects (figure 2) (photo 3). The total surface areas inventoried were quite large given the difficulty of the terrain: forest 0.37 ha (0.18\%), old fallow 0.78 ha (0.08\%) young fallow 1.57 ha (0.06\%) and savannah 1.34 ha (0.08\%).

Volume tables were established from trees 5-15 years old felled in 14 plots distributed over four vegetation classes defined by remote sensing (Péroches, 2012). Field work consisted of measuring 5 main tree species (Albizia adianthifolia,
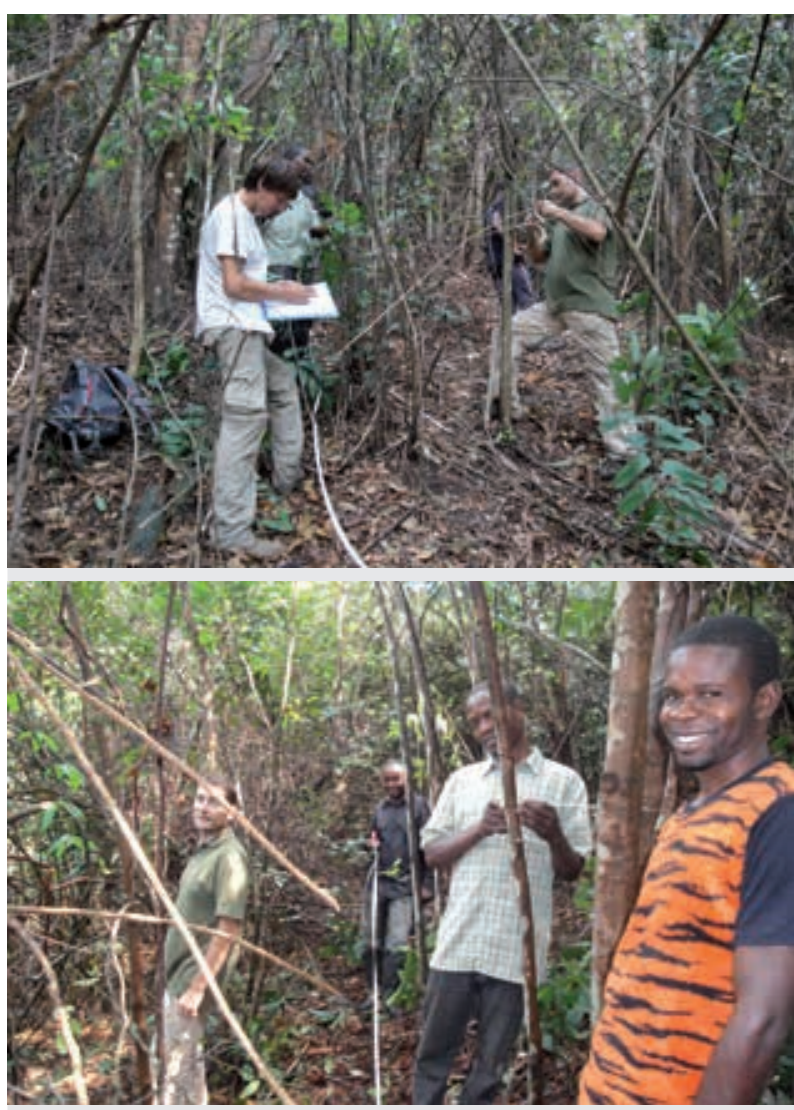

Photo 3.

Inventories on an old fallow, along the Lufimi River valley. Photos R. Peltier.

Table I.

Confusion matrix of the 2012 classification.

\begin{tabular}{|c|c|c|c|c|c|c|c|c|c|c|c|c|}
\hline Land cover & Water & Forest & $\begin{array}{c}\text { Old } \\
\text { fallow }\end{array}$ & $\begin{array}{l}\text { Young } \\
\text { fallow }\end{array}$ & Savannah & $\begin{array}{c}\text { Burnt } \\
\text { savannah }\end{array}$ & Crops & $\begin{array}{c}\text { Recent } \\
\text { burnt } \\
\text { area }\end{array}$ & $\begin{array}{c}\text { Bare } \\
\text { soil }\end{array}$ & Samples & $\begin{array}{l}\text { Producer } \\
\text { accuracy }\end{array}$ & $\begin{array}{c}\text { Omission } \\
\text { error }\end{array}$ \\
\hline Water & 307 & & & & & & & & & 307 & $100 \%$ & ०\% \\
\hline Forest & & 66 & 30 & & & & & & & 96 & $69 \%$ & $31 \%$ \\
\hline Old fallow & & 9 & 135 & 18 & 139 & 4 & & & & 305 & $44 \%$ & $56 \%$ \\
\hline Young fallow & & & 4 & 301 & 39 & & 5 & & & 349 & $86 \%$ & $14 \%$ \\
\hline Savannah & & & & & 1,009 & & 1 & & & 1,010 & $100 \%$ & ०\% \\
\hline Burnt savannah & & & & & & 94 & & 188 & & 282 & $33 \%$ & $67 \%$ \\
\hline Crops & & & & & & & 1 & & & 1 & $100 \%$ & ०\% \\
\hline $\begin{array}{l}\text { Recent burnt } \\
\text { area }\end{array}$ & & & & & & & & 15 & & 15 & $100 \%$ & ०\% \\
\hline Bare soil & & & & & & & & & 101 & 101 & $100 \%$ & ०\% \\
\hline Samples & 307 & 75 & 169 & 319 & 1,187 & 98 & 7 & 203 & 101 & 2,466 & & \\
\hline User accuracy & $100 \%$ & $88 \%$ & $80 \%$ & $94 \%$ & $85 \%$ & $96 \%$ & $14 \%$ & $7 \%$ & $100 \%$ & & & \\
\hline Commission error & $0 \%$ & $12 \%$ & $20 \%$ & $6 \%$ & $15 \%$ & $4 \%$ & $86 \%$ & $93 \%$ & ०\% & & $82 \%$ & $\begin{array}{c}\text { Overall } \\
\text { accuracy }\end{array}$ \\
\hline
\end{tabular}


Hymenocardia ulmoides, Markhamia tomentosa, Oncoba welwitschii, Pentaclethra eetveldeana) and a group of 6 secondary species (Dracaena mannii, Macaranga monendra, Millettia eetveldeana, Millettia laurentii, Sapium cornutum, Vitex congolensis). The height and dbh of 30 trees of each species were measured. The trees were then cut into billons. The length and circumference of each of these wood billons were measured at the large and small ends (minimum $13 \mathrm{~cm}$ ). Tree volume was calculated using the Smalian equation (Picard, 2015).

Using the Global Wood Density Database (Zanne et al., 2009), the mean wood density obtained was $0.546 \mathrm{t} / \mathrm{ha}$.

\section{Results}

\section{A $30 \%$ decrease of carbon stocks}

Four maps of vegetation types were produced for 1984, 2001, 2006 and 2012. Biomass and carbon estimation values were assigned to each class. An estimation of carbon stock was then calculated for each period and each vegetation type (figure 3). A net decrease of carbon stock clearly appears. Mainly forest and old fallow decreased drastically. Estimations for above ground biomass were: forest $75 \mathrm{t} / \mathrm{ha}$, old fallow $33 \mathrm{t} /$ ha, young fallow $6 \mathrm{t} / \mathrm{ha}$ and savannah $3 \mathrm{t} / \mathrm{ha}$. Carbon stock was: forest $38 \mathrm{t} /$ ha, old fallow $17 \mathrm{t} / \mathrm{ha}$, young fallow $3 \mathrm{t} /$ ha and savannah $1.5 \mathrm{t} / \mathrm{ha}$. The carbon stock (tons) dynamic within the wood-fuel supply basin of Kinshasa consequently shows a 30\% loss over the 28 -year period (-1\% per year on average).

\section{Local trends}

The study revealed some local trends. The example of Mampu, where 8,000 hectares of Acacia auriculiformis were planted between 1987 and 1993 (Bisiaux et al., 2009), is presented in figure 4. The 1984 map shows the situation before the plantations were set up. By 2001, the plantations were mature. On the 2001 map, forest covers an important surface area but logging and cultivation have already modified the plantations (photo 4). Strips are visible corresponding to squares allocated to charcoal production and cultivation. The area of old tree regrowth is large. In 2006, the situation is totally different. Logging is intense and mainly supported by old regrowth. In 2012, the phenomenon has become worse with the quasi disappearance of forest and old regrowth. Carbon stock has dropped dramatically.

In the Bas-Congo region, the dynamics of change were different (figure 5). Carbon stock was high in 1984 relative to the small surface covered by forest. By 2001, the forest had almost disappeared, and by 2006 it had totally disappeared. The situation was even worse in 2012 when even young fallow had severely decreased (Nsimundele, 2010).

\section{Discussion and conclusion}

This article has described how the Makala project developed dynamic maps of surface states from satellite imagery, and how these maps were documented with field data to estimate stock biomass and therefore carbon. The analysis of the maps highlighted the evolutionary trends of the stock at the level of the supply area and of village territories. This picture helps identify the dangers and threats to wood energy resources in the context of rapid population growth in Central Africa. These data are very important to guide public policies on domestic energy and the development of agriculture, forestry and agroforestry (Gautier et al., 2011).

Despite the low inventory levels, this study clearly confirms what was suggested in the satellite study by Megevand (2014), namely a sharp deterioration of forest formations on the outskirts of Kinshasa over the past few decades. It clearly shows that the analysis of land cover change helps to understand and document the spatial organization and mechanisms of forest degradation.

Given the sharp decline in wood energy and carbon stocks in the supply basin of Kinshasa demonstrated by this study, the Ministries of Energy, Agriculture and the Environment should develop strategies to stabilize or reduce the consumption of wood energy, develop more intensive cropping systems with less reliance on the burning of forests, and encourage people to sustainably manage their environment (Neufeldt et al., 2015). To test some solutions, the Makala project has proposed a strategy based on: i) land security (Vermeulen et al., 2011) and management of village lands (Dubiez et al., 2013); ii) the development of Assisted Natural Regeneration (ANR), a technique which can be used by slashand-burn farmers in the ecological and social context of the DRC that does not upset the farmers' habitual routines, involve payment incentives, or require supplementary material (Peltier et al., 2015); and iii) plantations of acacias and



Figure 3.

Carbon stock evolution from 1984 to 2012 for the four types of vegetation in the wood-fuel supply basin of Kinshasa. 




Figure 4.

Vegetation maps of Mampu from 1984 to 2012 (left), surface area (in hectares) for each vegetation type (top right) and carbon stock (in metric tons) for each vegetation type (bottom right).



Figure 5.

Vegetation maps of Kinduala (Bas-Congo) from 1984 to 2012 (left), surface area (in hectares) for each vegetation type (top right) and carbon stock (in metric tons) for each vegetation type (bottom right).

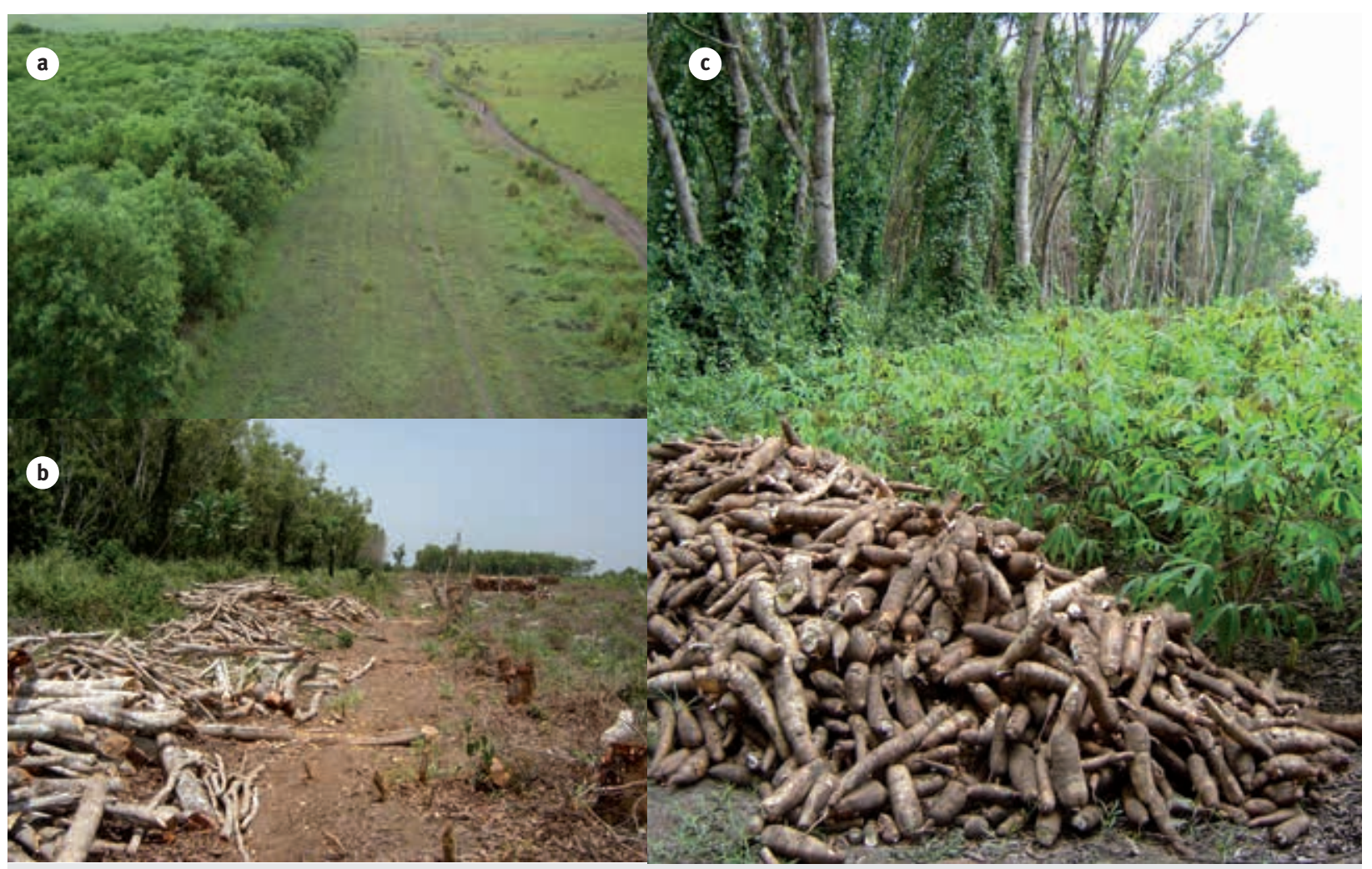

Photo 4.

Mampu, on the savannahs of the Bateke plateau. A plantation of Acacia auriculiformis aged about twenty years (a).

Acacia wood waiting carbonization following the exploitation of a plot (b). Harvest of cassava that was grown after the slashing and burning of an acacia parcel (c).

Photos R. Peltier. 
other species of leguminous trees when tree vegetation has become too rare in fallows (Bisiaux et al., 2013) (photo 5).

While the Makala project has pointed the way forward, a wood-fuel supply scheme now needs to be developed for the city of Kinshasa similar to those that have been developed in many cities of the Sahel since the 1990 (Ribot, 2003;
Rives et al., 2012). This would involve setting up a management system for the remaining forests, disseminating largescale agroforestry throughout the supply basin and implementing an energy saving and substitution policy (gas, electricity) as has been proposed by the World Bank for Niger (Cirad et al., 2015). Indeed, if the biomass and biodiversity of

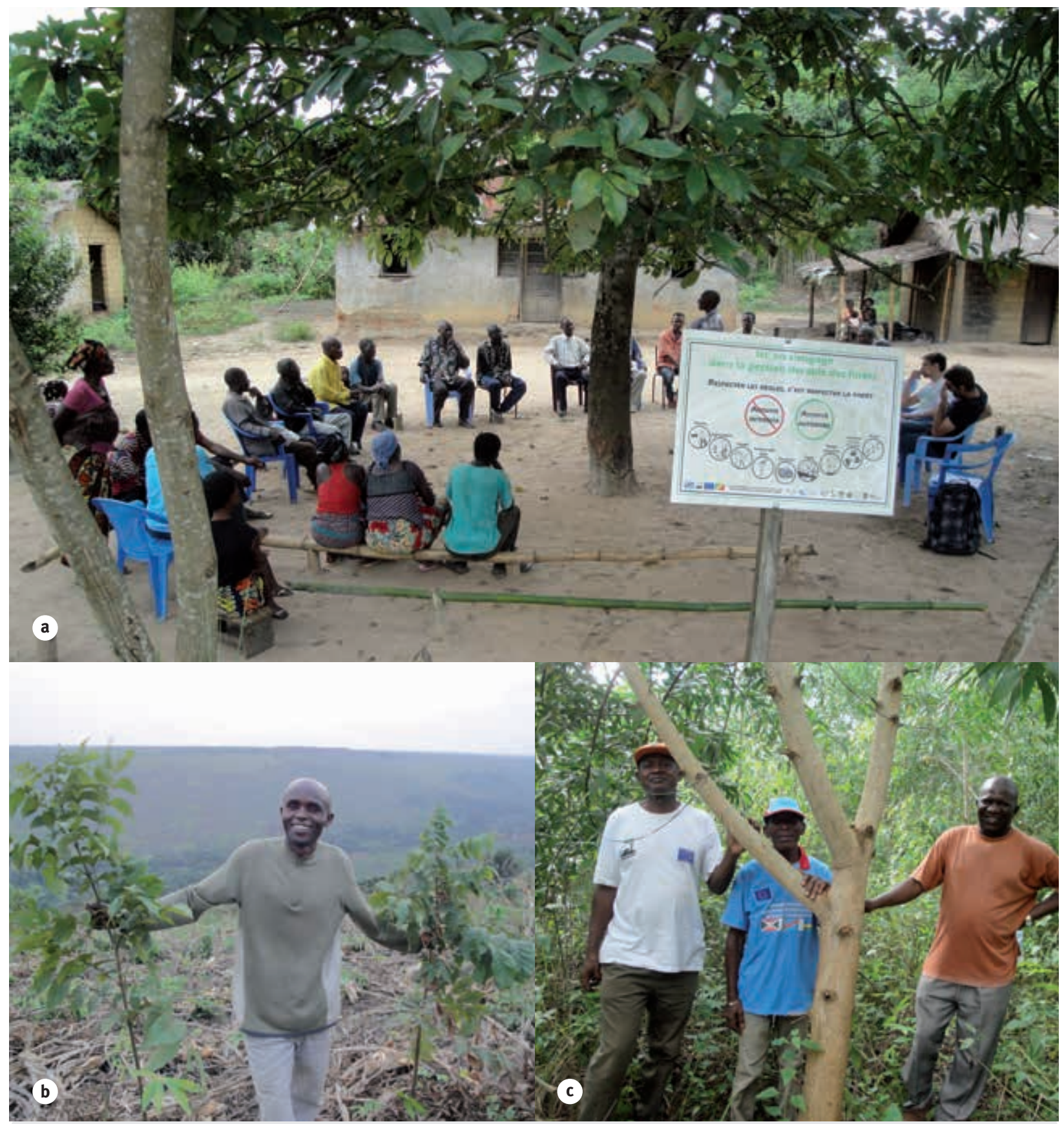

Photo 5.

To restore degraded areas, the Makala project proposed a strategy based on: Land security and management of village lands (a);

Development of Assisted Natural Regeneration (b); Plantations of acacias when the tree vegetation has become too rare in the fallows (c). Photos R. Peltier. 
the tree formations of the Kinshasa region are to be rebuilt while ensuring coverage of the energy needs of a rapidly growing population, it is absolutely necessary that some of this energy comes from other sources. Hydroelectric dams under construction or renovation (Inga) on the falls of the Congo River, the most powerful in the world, should help.

\section{Acknowledgements}

The authors specially thank all of the Makala project workers who were actively involved in inventory and data collection for the preparation of the volume tables, in particular Simon Diowo, Timothée Yamba Yamba, Sabu Mbono Wakambo, and Samuel Lufungula, as well as the EC for its financial support (EuropeAid DCI-ENV 2008-151-384). http://makala.cirad.fr

\section{Bibliographical references}

Anglo-French Forestry Commission, 1973. Rapport de la mission forestière Anglo-Francaise Nigeria-Niger (décembre 1936 - février 1937). Bois et Forêts des Tropiques, 148: 3-26. http://bft.cirad.fr/cd/BFT_148_3-26.pdf

Bisiaux F., Peltier R., Muliele J.-P., 2009. Plantations industrielles et agroforesterie au service des populations des plateaux Batéké, Mampu, en République démocratique du Congo. Bois et Forêts des Tropiques, 301 (3): 21-31. http://bft.cirad.fr/cd/BFT_301_21-32.pdf

Bisiaux F., Diowo S., Lufungula S., Mbono-Wakambo S., Mafinga J.-P., Matungulu P., Lebou L., Dubiez E., Louppe D., Marien J.-N., 2013. Réintroduire l'arbre dans le système cultural : succès et difficultés de l'agroforesterie villageoise. In : Marien J.-N., Dubiez É., Louppe D., Larzillière A. (éds). Quand la ville mange la forêt. Les défis du bois-énergie en Afrique centrale. Versailles, France, Éditions Quæ, p. 149-155.

Boulogne M., Pennec A., Dubiez E., Gigaud M., Péroches A., Lavialle J., Rerolles J., Proces P., Peltier R., Marien J.-N., Gond V., 2013. Évolution du couvert végétal et des stocks de carbone dans le bassin d'approvisionnement de Kinshasa. In : Marien J.-N., Dubiez É., Louppe D., Larzillière A. (éds). Quand la ville mange la forêt. Les défis du bois-énergie en Afrique centrale. Versailles, France, Éditions Quæ, p. 45-59.

Cirad, IDA, BEIE, CTFC, 2015. Programme National des Énergies Domestiques du Niger. Rapport final. Banque Mondiale, Washington, USA.

Dubiez E., Vermeulen C., Larzillière A., Proces P., Diowo S., Yamba-Yamba T., Mvolo B., Wakambo S., Inzamba J., Mubilayi Kabeya F., Marien J.-N., 2013. Les plans simples de gestion pour les ressources des communautés. In : Marien J.N., Dubiez É., Louppe D., Larzillière A. (éds.). Quand la ville mange la forêt. Les défis du bois-énergie en Afrique centrale. Versailles, France, Éditions Quæ, p. 63-76.
Duveiller G., Defourny P., Desclée B., Mayaux P., 2008. Deforestation in Central Africa: estimates at regional, national and landscape levels by advanced processing of systematically-distributed landsat extracts. Remote Sensing of Environment, 112: 1969-1981.

Fischetti M., 2015. This land is my land. Scientific American 312, 90 (2015). Published online: 14 April 2015 | doi:10.1038/ scientificamericano515-90

Floret C., Pontanier R., 2000. La jachère en Afrique Tropicale. Rôles, Aménagement, Alternatives. Actes du Séminaire international, Dakar, 13-16 avril 1999. Paris, France, John Libbey Eurotext, $777 \mathrm{p}$.

Gautier D., Hautdidier B., Gazull L., 2011. Woodcutting and territorial claims in Mali. Geoforum, 42: 28-39.

Gigaud M., 2012. Étude sur l'état des jachères forestières du Plateau Batéké, par inventaire des forêts-galeries et évaluation de la possibilité de les restaurer, par mesure des placettes de suivi des essais de Régénération Naturelle Assistée (RNA) réalisés par le projet Makala. Mémoire présenté pour l'obtention du Master 2 "Ecosystèmes Terrestres ». Montpellier, France, Université d'Orléans, CIRAD, 31 p.

Gond V., Dubiez E., Boulogne M., Pennec A., Peltier R. 2015. Evolution of plant cover and carbon stock in the fuelwood supply basin of Kinshasa (D. R of Congo). In: ESA. 1st BIOMASS Science Workshop, Rome, Italy, 27-30 January 2015. s.l. : s.n., résumé, 1 p. BIOMASS Science Workshop. 1 , 2015-01-27/2015-01-30, Rome, Italie.

Katembera Ciza S., Mikwa J.-F., Cirhuza Malekezi A., Gond V., Boyemba-Bosela F., 2015. Identification des moteurs de déforestation dans la région d'Isangi, République démocratique du Congo. Bois et Forêts des Tropiques, 324 (2) : 29-38. http://bft.cirad.fr/cd/BFT_324_29-38.pdf

Kergomard C., 2000. Pratique des corrections atmosphériques en télédétection : utilisation du logiciel $5 \mathrm{~S}$-PC. Cybergeo : European Journal of Geography, 181. doi : 10.4000/ cyberge 0.1679

Marquant B., 2011. Évaluation socio-économique, agronomique et forestière des premiers essais de Régénération Naturelle Assistée (RNA) réalisés par le projet Makala sur le plateau Batéké, en République démocratique du Congo. Mémoire de césure. SupAgro-Cirad, Montpellier, France, 109 p.

Megevand C., 2014. Dynamiques de déforestation dans le bassin du Congo. Réconcilier la croissance économique et la protection de la forêt. La Banque Mondiale, Washington D.C., USA, $179 \mathrm{p}$.

Molinario G., Hansen M., Potapov P., 2015, Forest cover dynamics of shifting cultivation in the Democratic Republic of Congo: a remote sensing-based assessment for 2000-2010, Environmental Research Letters, 10. doi:10.1088/17489326/10/9/094009 
Neufeldt H., Dobie P., liyama M., Njenga M., Mohan S., Neely C., 2015. Developing sustainable tree-based bioenergy systems in sub-Saharan Africa. ICRAF Policy Brief No. 28. Nairobi, Kenya, World Agroforestry Centre (ICRAF).

Nsimundele Nkondo L., Diansambu Makanua I., Dubiez E., Proces P., Marien J., Peltier R., Vermeulen C., 2010. Conserver ou manger la forêt ? Le paradoxe des paysans en périphérie de Kinshasa, RDC. Aires protégées traditionnelles du BasCongo. Le Flamboyant, 66/67:33-37.

Oszwald J., Gond V., Dodelec S., Lavelle P., 2011. Identification d'indicateurs de changement d'occupation du sol pour le suivi des mosaïques paysagères. Bois et Forêts des Tropiques, 307 (1) : 7-21. http://bft.cirad.fr/cd/BFT_307_721.pdf

Peltier R., Dubiez E., Diowo S., Gigaud M., Marien J.-N., Marquant B., Péroches A., Proces P., Vermeulen C., $2014 a$. Assisted Natural Regeneration in slash-and-burn agriculture: Results in the Democratic Republic of the Congo. Bois et Forêts des Tropiques, 321 (3): 57-69. http://bft.cirad.fr/cd/ BFT_321_67-79.pdf

Peltier R., Dubiez E., Freycon V., Marien J.-N., Marquant B., Péroches A., Diowo S., Yamba Yamba T., Palou Madi O., 2014 b. From the Sahara to the Congo River, combining assisted natural regeneration and land tenure security to improve slash-and-burn agriculture. World Congress on Agroforestry (WCA 2014), Delhi, India, 10-14 February 2014, poster.

Peltier R., Dubiez E., Marquant B., Péroches A., Diowo S., Yamba Yamba T., Palou Madi O., 2015. Landscape management to develop agroforestry in Central-Africa. In: 3 rd Climate-Smart Agriculture 2015: Global Science Conference, March 16-18, 2015, Montpellier, France. s.l. : s.n., [1] p. Climate-Smart Agriculture 2015: Global Science Conference. 3, 2015-03-16/2015-03-18, Montpellier, France.

Péroches P., 2012. Étude sur l'évolution de la biomasse au niveau de terroirs du Plateau Batéké en République Démocratique du Congo. Impact des systèmes de culture et des techniques agroforestières telles que la Régénération
Naturelle Assistée promues par le projet Makala. Mémoire de césure. Montpellier, France, SupAgro, IRC, Cirad, 79 p.

Picard N., 2015. Inventaires forestiers, Dendrométrie. In : Mémento du Forestier Tropical. Billand D., Louppe D., Jourdan-Ruf C., Mille G., Sist P., (éds.). Éditions Quæ, Versailles, France, p. 460-490.

Ribot J. C., 2003. Democratic decentralization of natural resources: Institutional choice and discretionary power transfers in sub-Saharan Africa. Public Administration and Development, 23 (1).

Rives F., Peltier R., Montagne P., 2012. Fifteen Years of Forest Community Management in Niger: from a Technician's Dream to Social Reality. Small-scale Forestry. Springer, New-York, USA and Heidelberg, Germany. doi: 10.1007/s11842-0129203-5

Schure J., Ingram V., Akalakou-Mayimba C., 2011. Bois énergie en RDC : Analyse de la filière des villes de Kinshasa et de Kisangani. Kinshasa, République démocratique du Congo, Projet Makala, Cifor, 88 p.

Schure J., 2014. Woodfuel for urban markets in the Congo Basin: a livelihood perspective. PhD thesis, Wageningen University, Wageningen, Netherlands, $186 \mathrm{p}$.

Vancutsem C., Pekel J.-F., Evrard C., Malaisse F., Defourny P., 2009. Mapping and characterizing the vegetation types of the Democratic Republic of Congo using SPOT-VEGETATION time series. International Journal of Applied Earth Observation and Geoinformation, 11: 62-76.

Vermeulen C., Dubiez E., Proces P., Diowo Mukumary S., Yamba Yamba T., Mutambwe S., Peltier R., Marien J.-N., Doucet J.-L., 2011. Enjeux fonciers, exploitation des ressources naturelles et Forêts des Communautés Locales en périphérie de Kinshasa, RDC. Biotechnology, Agronomy, Society and Environment, 15 (4) : 535-544.

Zanne A. E., Lopez-Gonzalez G., Coomes D. A., Ilic J., Jansen S., Lewis S. L., Miller R. B., Swenson N. G., Wiemann M. C., Chave J., 2009. Global wood density database. Dryad Digital Repository. 